\title{
Family Dental Health Care Service
}

\author{
Riana Wardani \\ Department of Public Health, Faculty of Dentistry Universitas Padjadjaran
}

\begin{abstract}
The Family Dental Health Care Service is a new approach that includes efforts to serve oral and dental patients that focuses on maintenance, improvement and protection. This oral and dental health approach uses basic dentistry science and technology. The vision of the Family Dental Health Care Service is the family independences in effort of dental health maintenance and to achieve the highest oral and dental health degree as possible through family dentist care that is efficient, effective, fair, evenly distributed, safe and has a good quality. To support this effort, the Ministry of Health has issued Health Care Policy and Implementation Guideline as well as the license standard for family dentist practice.
\end{abstract}

Key words: Health care services, family dentist

\section{INTRODUCTION}

Oral and dental diseases are diseases that are widely spread among the Indonesians. ${ }^{1}$ The results from Household Health SurveyNational Health Survey/SKRT-Suksesnas morbidity study 2001 shows that from the top 10 diseases experienced by the community, dental disease is at the first rank (National Health Survey/Suksesnas: $60 \%$ of the population). ${ }^{2}$ This condition will surely affect the quality of life if it is related to work productivity disorders (Suksesnas 1998: $62.4 \%$ of the population is disturbed in their work/school because of dental problem with the average of 3.8 days per year. ${ }^{3}$

The dental caries and the gingival diseases are the most common dental problems complained by the population. The results of SKRT 2001 study show that 52.3 percent of population in the $<10$ years old age group experience unmanaged dental caries. The pathetic part of this problem which is revealed in SKRT is that the motivation to fill caries teeth is very low, only 4-5 percent, while the unmanaged dental damaged reaches 82.5 percent. ${ }^{2}$ The causing factors of this oral and dental diseases are affected by the environmental, behavioral and dental and oral health service factors. ${ }^{5,6}$

Various efforts to deal with this problem have been performed either by the government or by the private sectors. The steps taken by the Government of Indonesia, in this case the Ministry of Health, is by improving oral and dental health degree of the Indonesian population by providing quality services in an efficient and effective manner in the primary level in the form of family dental service approach that is supported by the issuance of the Decision Letter from the Ministry of Health No. 1415/Menkes/SK/X/2005 on the Family Dental Care Policy that also includes a guideline and permit policy. ${ }^{2-4}$

The Family Dental Service is a new approach that is applied to improve oral and dental health service based on basic dental science and technology. 
The vision of the family dental service is to achieve family independency in terms of dental health care effort to reach the highest level of oral and dental health possible through family dental care in an efficient, effective, fair, well distributed and good quality manner. ${ }^{2}$ To implement a family dental care, it is necessary that the dentists understand the rules that are included in the Family Dental Health Care Policy and Family Dental Health Care Implementation Guideline.

\section{Family Dental Health Care basic concept}

The Family dental service is an effort towards holistic oral and dental health service that focuses on services to each individual in the involved family. The service approach must be a holistic one that includes preventive, curative, and rehabilitative services by paying attention to the risk factors and referral system. In addition, the services given are integrated, continual and productive services and focus on the responsibility to maintain and improve the health of all members in one unit in a community or environment where the family lives. ${ }^{2,7}$

The Family dental care supports the independency of the family in maintain the oral and dental health by providing evenly distributed family dentist service with good quality as well as affordable and also by giving services, maintaining and improving individual dental health and community dental health (The families) to achieve expected dental and oral degree. This will also improve family dentist professionalism in doing his/her role, task and function by improving partnership with profession, educational institutions and related parties. In the Family Dental Care, the dentist is the first contact who is met by the patient/client to solve an oral and dental health problem and this dentist is also a referral screener for the next level of care.

The family dentist gives services to individuals (personal) considering the fact that each person is a part of his/her family so it will give an opportunity to understand patient's problem in a wider aspect by having a good relation with the patient's family. The medical decision made will consider not only the medical aspect but also social, cultural and economic aspects of the patient and his/her family.
The service provided will be a comprehensive service using the approach of maintenance, health improvement (promotion), disease prevention (preventive), curative and rehabilitative according to the patient's need by putting emphasize on promotion, specific protection, detection and early management that has an orientation towards the health paradigm. The health paradigm in family dental health will be able to encourage the community to be independent in maintaining their own health through a good awareness towards the importance of promotive and preventive health care.

The continuous Family Dental Care will focus on patient oriented approach using the principles that support long term relationship between the dentist and the patient in terms of health care. Besides, the family dentist will act as the coordinator to take care of everything that relates to patient oral and dental health including consultation with other disciplines, referral to specialists and giving clear information to the patient when the patient need services beyond the dentist competency. In addition, the dentist also considers the influence of the patient's condition to the family in dealing with the problem without leaving out the influence of the environmental, social and cultural factors in the places where the patient lives and work by paying attention to the impact of the patient's condition to the community and vice versa (family and community oriented). ${ }^{2,3}$

\section{Family dentist competency}

The scope of the family dentist work and the scope of family unit substance is given in the specific competencies that should be acquired by the family dentist that will make him/her different from the general dentist. Schematically, the flow chart competency used can be described in the Table. ${ }^{2}$

\section{Family Dental Care Service efforts}

The efforts in the Family Dental Care Service are categorized into two categories:2,3 Basic dental care service, which is the basic effort package that should be performed to meet the needs of the essential dental and oral health including emergency care, prevention care and simple treatment, and Advance Family Dental Health 
Table 1. Flow chart competency

\begin{tabular}{|c|c|c|}
\hline No & $\begin{array}{l}\text { Field (according to family growth and } \\
\text { development and problems) }\end{array}$ & Competency needed \\
\hline 1. & $\begin{array}{l}\text { Fetal phase } \\
\text { - Growth and development } \\
\text { - Diet, nutrition }\end{array}$ & - Nutrition and diet analysis, counseling \\
\hline 2. & $\begin{array}{l}\text { Pregnant women } \\
\text { - Hormonal disorders } \\
\text { - Oral and dental diseases } \\
\text { - Oral hygiene } \\
\text { - Pregnant woman behavior \& motivation }\end{array}$ & $\begin{array}{l}\text { - Risk factors identification } \\
\text { - Behavior and habit modification }\end{array}$ \\
\hline 3. & $\begin{array}{l}\text { Children } \\
\text { - Pedodontic clinical problem } \\
\text { - Children bad habit } \\
\text { - Malocclusion initial problem }\end{array}$ & $\begin{array}{l}\text { - Behavioral change } \\
\text { - Pediatric patient management } \\
\text { - Early diagnosis and appropriate care } \\
\text { - Risk factor identification, } \\
\text { - Orthodontic for early diagnosis and prompt care. }\end{array}$ \\
\hline 4. & Adolescent & - Hormone-related, orthognatic, and esthetical oral-dental problems \\
\hline 5. & $\begin{array}{l}\text { Father } \\
\text { - Systemic disease } \\
\text { - Oral and dental disease } \\
\text { - Smoking and stress } \\
\text { - Family health funding } \\
\text { - Family decision making }\end{array}$ & $\begin{array}{l}\text { - Adult patient clinical intervention } \\
\text { - Control on smokers } \\
\text { - Stress management } \\
\text { - Risk factor management } \\
\text { - Family health fund organization }\end{array}$ \\
\hline 6. & Geriatrics & - Geriatric problems \\
\hline 7. & $\begin{array}{l}\text { Patient provider relationship } \\
\text { - Fear \& anxiety } \\
\text { - Dissatisfaction } \\
\text { - Disbelief } \\
\text { - Perceived high cost for service }\end{array}$ & $\begin{array}{l}\text { - Fear and anxiety management } \\
\text { - Communication \& education } \\
\text { - Comfortable clinic arrangement } \\
\text { - Care according to SOP } \\
\text { - Diagnosis and clinical treatment }\end{array}$ \\
\hline 8. & $\begin{array}{l}\text { Management } \\
\text { - Sickness fund } \\
\text { - Funding } \\
\text { - HR data } \\
\text { - Facility and logistic data } \\
\text { - Waste management }\end{array}$ & $\begin{array}{l}\text { - Clinical epidemiological data management } \\
\text { - Funding } \\
\text { - HR management } \\
\text { - Logistic management } \\
\text { - Waste management }\end{array}$ \\
\hline 9. & $\begin{array}{l}\text { Ethics and legal aspects in family dental care. } \\
\text { The problems: } \\
\text { - Ethical violation } \\
\text { - Malpractice } \\
\text { - Violation of a third party agreement } \\
\text { - Legal violation }\end{array}$ & $\begin{array}{l}\text { - Basic principles of Medical Legal Ethic and its relationship with } \\
\text { Medical Practice Regulation }\end{array}$ \\
\hline
\end{tabular}

Care service which includes additional effort package that is given based on the oral and dental problem found in the community and is adapted to the capacity of the family dentist. In this respect a moderate care which needs certain specialist care with referral or support system can be provided. The Family Dentist Care to maintain and improve oral and dental health in the families involved should apply regional system and community empowerment principles. ${ }^{2,3}$

The regional responsibility means that all family dentists in a work area have the responsibility to improve the health degree of the population in the work area. Each family dentist is responsible for 500 households or 2,500 people. In terms of community empowerment the family dentist has the responsibility to empower individuals, families, and the community to play active roles in family dental health care through, among others, Posyandu cadres, school dental care unit, Posyandu Usila cadres, geriatric care institutions, occupational health effort post cadres, religion leaders, community leaders, private sectors and the community.

\section{Family Dental Health Care Service model}

The Family dental health care can be developed into several models such $\mathrm{as}^{7}$ : (1) Individual practitioner as family dentist The family dental health care service that is developed based on the initiative of the dentist and the dental nurse and according to the existing permit standard including having a certificate of Family Dental Health Care Education Program (FDHCEP) or have 
received special training that trains dentists into family dentists according to the expected competencies. (2) Family dentist team. The family dentist team work together to serve the families as partners working under a family dental health care system that use clinical standards and health insurance appropriate for family dentist.

\section{Service scope}

The Dental Health Care Service is performed using levels of care system through a referral system using Primary Health Care Approach which is to give comprehensive services in levels of service that are related to the existing resources in the community. The family dental health care unit is run by a team of family dentists and dental nurses with clear job description. ${ }^{3}$

The scope of work for dentist include 4 aspects that include Basic Emergency Care with basic life support/first aid for emergency that is performed before the patient is referred if necessary, pain reduction and/or infection elimination/first aid in oral/dental problem due to diseases/injuries, TMJ dislocation reposition, dental replantation and occlusion adjustment (acute).

The second aspect is the preventive care that includes dental health education (individual/ group), bad habit elimination, special protection action, early detection \& prompt treatment and advocacy to manage saliva and nutrition problems.

The third aspect is the simple basic medical care that includes dental filling (glass ionomer/resin composite/combination filling), dental extraction (persistent primary teeth/permanent teeth due to a disease/orthodontic need/serial extraction (primary teeth), pulp care (pulp capping/ pulpotomy/anterior dental root canal treatment), abscess treatment/care, dry socket management, recurrent ulcer (aphtosa) treatment, and halitosis management. The fourth aspect includes special dental medical care/moderate care that includes dental conservation, pedodontic, periodontic, oral surgery, orthodontic, prosthodontic and oral medicine.

\section{Human resource improvement}

An appropriate human resource need should be managed based on the number of families or the population in Indonesia. The ratio of family dental team to the number of family is ideally $1: 500$ households or 2,500 population. All health care workers who are actively involved in the family dental care should have received family dental care education or a training on Family Dental Health Care Service. The training and education of family dentist is held by the Ministry of Health in cooperation with education institutions (faculty of dentistry) and professional organization. ${ }^{3,4,8}$

\section{Funding system}

The format of IHE (Individual Health Effort) funding is as stated in the National Health System (NHS): (1). Fund for IHE from individuals in a family unit is through obligatory Health Care Security (HCS) and voluntary Health Care Security (HCS) (2) Fund for vulnerable community and poor family IHE comes from the government through obligatory Health Care Security (HCS) (3) The community fund (Health Fund and Social/Religion Fund) is used for CHE and IHE.

In the Health Security System, using pre effort payment received from the steering institution of Health Care Security (HCS), the family dentist as the Health Care Provider (HCP) will emphasize on the promotive and preventive efforts with curative and rehabilitative service provided according to the need. ${ }^{2,7,9}$

\section{Family Dental Care Service Practice License}

The license for family dental care service practice is a must for holding a family dental practice to give a quality care that is safe and comfortable for the community. The authority of giving license is given to the authorized body according to the Law No. 32 year 2004 on Local Autonomy; Law No. 29 year 2005; Perkonsil No. 1 year 2005 and the Instruction from the Minister of Health No. 1419/2005 with the District/City government as the authority for giving practice license to doctors and dentists including family dentists. ${ }^{2,3}$

\section{Guidance and supervision}

The guidance and supervision is aimed at improving health care given by the dentists, protecting the community from the actions performed by the dentist and giving legal assurance for the community and the dentist. The supervision 
is used to protect everyone so that the service quality will be maintained and if a deviation from standard is found, it can be identified soon and an intervention can be easily implemented.

Guidance and supervisory actions are performed by the Central Government, Indonesian Medical Council, Local Government (Provincial Health Office, District/City Health Office) and professional organization. ${ }^{2,3}$

\section{CONCLUSION}

Family dental health care is a comprehensive individual basic health care service in oral and dental health that focuses its service to individuals in the family under the scheme by using basic health science and technology (including dentistry) that is performed by individuals, community and government through promotive, preventive, curative, and rehabilitative effort in the form of outpatient and inpatient services. The dentists who provide family dental care service are the licensed dentists who have followed training and have a certificate as family dentist as well as meeting the requirements of the family dental health care standard.

\section{REFERENCES}

1. Hapsara HR. Pembangunan kesehatan di Indonesia. Yogyakarta: Universitas Gajah Mada Press; 2004.
2. Direktorat Jendral Bina Pelayanan Medik, Direktorat Pelayanan Medik Dasar. Kebijakan pelayanan kedokteran gigi keluarga. Jakarta: Ministry of Health of Indonesia; 2006. p. 1832.

3. Direktorat Jendral Bina Pelayanan Medik, Direktorat Pelayanan Medik Dasar. Pedoman pelayanan kedokteran gigi keluarga. Jakarta: Ministry of Health of Indonesia; 2006. p. 412.

4. Direktorat Jendral Bina Pelayanan Medik, Direktorat Pelayanan Medik Dasar, Modul Pelatihan dokter gigi keluarga. Jakarta: Ministry of Health of Indonesia; 2006 p. 1-4.

5. Pine CM. Community oral health. Boston: Reed Educational \& Proff Publish Ltd.; 1997. p. 12.

6. Jong's. Community dental health. $5^{\text {th }}$ ed. St. Louis: Mosby Co.; 2003. p. 3-31.

7. Permadi. Bunga rampai dokter keluarga. Jakarta: Kelompok Studi Dokter Keluarga; 1983.

8. Modul pelatihan untuk pelatih pelayanan kedokteran gigi keluarga. Jakarta: KKI; 2006. p. 3-5.

9. Azwar A. Kebijakan pembiayaan dan jaminan kesehatan. Jakarta: Ditjen Bina kesehatan masyarakat; 2002.

10. Yubiliana G, Wardani R. Pelayanan kedokteran gigi keluarga bagi pegawai dan Keluarga beserta pensiunan salah satu Bank di Bandung. Plaque J Kesehatan Gigi Masyarakat. 2007 Jun: 1(2):41-6. 